\title{
PENGARUH SPIRITUALITAS DALAM KINERJA GURU MELALUI MODAL PSIKOLOGIS DI SMP MUHAMMADIYAH MAGELANG
}

\section{THE INFLUENCE OF SPIRITUALITY ON TEACHER PERFORMANCES THROUGH PSYCHOLOGICAL CAPITAL AT JUNIOR HIGH SCHOOL OF MUHAMMADIYAH MAGELANG}

\author{
Imron $^{1}$, Idi Warsah ${ }^{2}$ \\ ${ }^{1}$ Universitas Muhammadiyah Magelang, Jl. Mayjend. Bambang Soegeng, Meryudan, Magelang 56172 \\ ${ }^{2}$ Institut Agama Islam Negeri (IAIN) Curup Bengkulu, Jl. Dr. AK. Gani No. 01 Kel. Dusun Curup, Rejang Lebong, \\ Bengkulu 39117 \\ Email: idiwarsah@iaincurup.ac.id
}

Naskah Diterima: 28 Juli 2019; Direvisi: 22 Agustus 2019; Disetujui: 02 Oktober 2019

\begin{abstract}
The purpose of this study was to determine the role of spirituality in teacher performance seen from the organizational commitment of Muhammadiyah Middle School teachers in Magelang Regency. This research is a quantitative study that is correlational, namely research that is asking the relationship between two or more variables. The population in this study were all Muhammadiyah Middle School teachers in Magelang Regency with 370 teachers, while the total sample in this study was 185 teachers. To conduct data analysis in this study, then: (1) analysis techniques with descriptive statistics; (2) technical analysis of multiple regression; and (3) path analysis techniques. Based on the results of research and discussions that have been conducted, the results of this study are (1) Spirituality has a very significant role in influencing teacher performance through organizational commitment, Muhammadiyah Middle School teachers in Magelang Regency; (2) Spirituality directly affect teacher performance, although not as much as if it is through organizational commitment variables; and (3) Teachers who have high spirituality will have good performance because they have high organizational commitment.
\end{abstract}

Keywords: Performance; Psychological Capital; Spirituality

\begin{abstract}
Abstrak
Tujuan penelitian ini adalah untuk mengetahui peran spiritualitas dalam kinerja guru dilihat dari komitmen organisasi pada guru SMP Muhammadiyah di Kabupaten Magelang. Penelitian ini merupakan penelitian kuantitatif yang bersifat korelasional, yaitu penelitian yang bersifat menanyakan hubungan antara dua atau lebih variabel. Populasi pada penelitian ini adalah seluruh guru SMP Muhammadiyah di Kabupaten Magelang yang berjumlah 370 guru, sedang jumlah sampel dalam penelitian ini berjumlah 185 guru. Untuk melakukan analisis data pada penelitian ini, maka digunakan (1) teknik analisis dengan statistik deskriptif; (2) teknis analisis regresi ganda; dan (3) teknik analisis jalur (path analysis). Berdasarkan hasil penelitian dan pembahasan yang telah dilakukan, maka hasil penelitian ini, yaitu (1) Spiritualitas mempunyai peran sangat signifikan dalam mempengaruhi kinerja guru melalui komitmen organisasi, guru SMP Muhammadiyah di Kabupaten Magelang; (2) Spiritualitas secara langsung mempengaruhi kinerja guru meskipun tidak sebesar jika melalui variabel komitmen organisasi; dan (3) Guru yang memiliki spiritualitas yang tinggi akan memiliki kinerja yang bagus karena memiliki komitmen organisasi yang tinggi.
\end{abstract}

Kata Kunci: Kinerja; Modal Psikologis; Spiritualitas 


\section{PENDAHULUAN}

Undang-Undang Republik Indonesia Nomor 14 Tahun 2005 Pasal 1 tentang Guru dan Dosen menyebutkan bahwa guru adalah pendidik profesional dengan tugas utama mendidik, mengajar, membimbing, mengarahkan, melatih, menilai dan mengevaluasi peserta didik pada pendidikan anak usia dini melalui jalur pendidikan formal, pendidikan dasar dan pendidikan menengah (Depdiknas, 2005). Sebagai konsekuensi logis dari amanat dari Undang-Undang di tersebut, pendidikan seharusnya dijalankan dengan baik oleh para pemangku kepentingan, baik pemerintah, masyarakat, dan sekolah, termasuk guru.

Melalui cara yang serius dan terprogram, maka pendidikan dapat berjalan dengan baik, dan maksimal. Melihat hal di atas maka guru merupakan elemen kunci dalam sistem pendidikan, khususnya di sekolah. Komponen lain, mulai dari kurikulum, saranaprasarana, biaya, dan sebagainya tidak akan banyak berarti, apabila esensi pendidikan dan pembelajaran yaitu interaksi guru dengan peserta didik tidak dilaksanakan dengan baik. Begitu pentingnya peran guru dalam mentransformasikan ilmu-ilmu dalam pendidikan, yaitu sekolah tidak akan ada perubahan atau peningkatan kualitas tanpa adanya perubahan dan peningkatan kualitas guru.

Isu-isu spiritual sebenarnya telah menarik perhatian para peneliti dalam bidang psikologi (Khanifar dkk, 2010). Implikasi terhadap pengembangan organisasi, bahwa spiritualitas bukan sekedar bermanfaat terhadap pribadi-pribadi, namun demikian juga bermanfaat terhadap organisasi. Spiritualitas dipandang sebagai penyebab terhadap prevalensi tingkat komitmen di tempat kerja dan kemudian karyawan yang lebih berkomitmen akan bekerja lebih keras dan bahagia. Seseorang yang bekerja memiliki kebermaknaan maka memiliki hubungan korelasi yang signifikan dengan komitmen organisasi, baik afektif, berkelanjutan dan normatif (Mousa \& Alas, 2016).

Spiritualitas juga memiliki hubungan yang menarik terhadap psychological capital. Semakin tinggi tingkat spiritualitas maka semakin tinggi psychological capital yang dimiliki seseorang (Ancok, 2011). Penelitian Lalatendu Kesari Jena dan Rabindra Kumar
Pradhan juga menunjukkan bahwa ada hubungan yang signifikan antara modal psikologis karyawan dan spiritualitas di tempat kerja. Spiritualitas seseorang semakin baik akan menjadikan psychological capital semakin baik. Psychological semakin baik, lebih-lebih jika ditunjang kecerdasan emosi semakin baik. Posisi kecerdasan emosi dalam penelitian ini merupakan variabel moderating (Jena \& Pradhan, 2015).

Modal psikologis merupakan variabel yang memiliki pengaruh terhadap kinerja. Modal psikologis merupakan konstruksi individu yang positif dan berorientasi pada keberhasilan tujuan melalui kemampuan seseorang untuk menemukan berbagai jalan untuk sukses (Adestyani \& Nurtjahjanti, 2013). Individu dengan modal psikologis yang tinggi merasakan afek positif yang lebih sering dalam bekerja, bahkan modal psikologis memiliki hubungan yang signifikan dengan kinerja karyawan (Liwarto \& Kurniawan, 2015).

Uraian di atas menggambarkan bahwa spiritualitas merupakan dimensi yang mampu membentuk karakter perilaku seseorang, membentuk perilaku yang tenang, menjadikan pekerjaan sebagai sesuatu yang bernilai dan bermakna (Rahman, 2015). Spiritualitas mempunyai korelasi yang kuat terhadap sikap kerja seseorang (Hendrawan, 2009). Spiritualitas dapat digunakan untuk meningkatkan kinerja organisasi. Peningkatan kinerja individu dalam organisasi dipengaruhi oleh spiritualitas (Javanmard, 2012). Spiritualitas yang dimaksud adalah sesuatu yang luas bidang potensi manusia yang berhubungan dengan tujuan akhir, dengan entitas yang lebih tinggi, dengan Tuhan, dengan cinta, dengan kasih sayang, dan dengan tujuan (Tart, 1975).

\section{Pengembangan Model dan Kerangka Penelitian}

Spiritualitas mengajarkan orang untuk mengekspresikan dan memberi makna pada setiap tindakannya, sehingga bila ingin menampilkan kinerja yang baik maka dibutuhkan kecerdasan spiritual (Sulastri, dkk, 2016). Kecerdasan tersebut menempatkan perilaku dan hidup kita dalam konteks makna yang lebih luas dan kaya, kecerdasan untuk menilai bahwa tindakan atau jalan hidup 
seseorang lebih bernilai dan bermakna (Zohar \& Marshall, 2002). Penelitian yang dilakukan oleh Milliman menyatakan bahwa spiritualitas di tempat kerja mempunyai korelasi yang kuat terhadap sikap kerja kru dan dapat digunakan untuk meningkatkan kinerja organisasi (Hendrawan, 2009). Dalam beberapa penelitian empiris lima tahun terakhir menunjukkan peningkatan produktivitas akibat spiritualitas di tempat kerja. Javanmard juga menunjukkan spiritualitas meningkatkan kinerja (Javanmard, 2012).

Spiritualitas diasumsikan memiliki pengaruh terhadap modal psikologis. Penelitian yang dilakukan oleh Zehra dan Husain (2015), menyebutkan bahwa nilai-nilai spiritual merupakan hal yang paling berharga bagi karyawan untuk pengembangan organisasi. Modal psikologis adalah faktor yang dapat membangun dan berkontribusi dalam keunggulan kompetitif organisasi. Studi ini meneliti hubungan antara nilai spiritual dan modal psikologis dari 100 guru dan 100 tenaga kependidikan dari Aligarh Universitas Muslim, Aligarh, India. Skala Nilai Spiritual dikembangkan oleh Husain, Zehra dan Jahan. Modal psikologis yang digunakan merupakan Angket yang dikembangkan oleh Luthans yang diberikan kepada responden. Data dianalisis dengan menggunakan alpha cronbach dan analisis regresi ganda. Alpha cronbach untuk total sampel ditemukan menjadi 0,947. Koefisien korelasi positif dan signifikan ditemukan antara hubungan nilai-nilai spiritual dan self-efficacy, nilai-nilai spiritual dan harapan, dan nilai-nilai spiritual dan modal psikologis baik laki-laki maupun perempuan dari responden. Korelasi positif yang signifikan juga ditemukan antara nilai-nilai spiritual dan self-efficacy, nilai-nilai spiritual dan harapan, nilai-nilai spiritual dan ketahanan, nilai-nilai spiritual dan optimisme, dan nilai-nilai spiritual dan modal psikologis secara keseluruhan pada guru dan karyawan.

Modal psikologis diasumsikan memiliki pengaruh terhadap kinerja individu dalam organisasi. Berdasarkan penelitian Liwarto dan Kurniawan (2015) disimpulkan bahwa variabel psychological capital memiliki hubungan yang signifikan dengan kinerja karyawan. Pada korelasi antara psychological capital dengan kinerja karyawan sebesar 0,652 menunjukkan hubungan yang positif, searah, dan kuat, signifikan pada $0,000<0,05$. Artinya bahwa kinerja karyawan berhubungan kuat dengan variabel psychological capital. Pada kondisi karyawan yang memiliki rasa percaya diri, harapan, optimisme, rasa pantang menyerah yang tinggi, ia juga akan memberikan hasil kinerja yang baik dan positif, atau juga dapat berlaku sebaliknya. Hal ini sejalan dengan penelitian Luthans dalam Liwarto (Liwarto \& Kurniawan, 2015), bahwa modal psikologi keseluruhan para karyawan di China memiliki hubungan positif dengan kinerja yang dinilai oleh para super-visornya. Oleh karena itu, terdapat hubungan yang positif antara modal psikologi secara keseluruhan dengan kinerja karyawan.

Spiritualitas juga diasumsikan memiliki pengaruh terhadap kinerja melalui modal psikologis. Penelitian Samiyanto tentang konstrak spiritualitas dan pengaruhnya terhadap psychological capital, servant leadership, dan kinerja manajer, menyimpulkan bahwa ada hubungan yang menarik antara spiritualitas dengan psichological capita (Ancok, 2011). Semakin tinggi tingkat spiritualitas maka semakin tinggi psychological capital manajer dan perilaku kepemimpinannya. Hasil lain dari penelitian ini bahwa spiritualitas tidak berpengaruh langsung terhadap kinerja manajer, tetapi melalui variabel mediasi servant leadership, artinya spiritualitas yang baik akan berpengaruh terhadap servant leadership. Servant leadership yang baik akan berpengaruh terhadap kinerja. Maka spiritualitas memiliki efek terhadap kinerja individu dalam organisasi baik secara langsung maupun melalui mediasi modal psikologis. Keterkaitan antara spiritualitas, kinerja dan modal psikologis guru dapat dilihat pada Gambar 1.

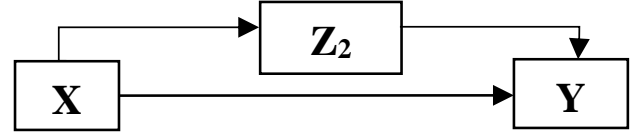

Gambar 1. Pengaruh spiritualitas terhadap kinerja melalui modal psikologis guru. Keterangan: $X=$ spiritualitas; $\mathrm{Y}=$ kinerja guru; $\mathrm{Z}_{2}=$ modal psikologis 


\section{METODE PENELITIAN}

Penelitian ini merupakan penelitian kuantitatif yang bersifat korelasional, yaitu penelitian yang bersifat menanyakan hubungan antara dua atau lebih variabel. Untuk mendapatkan pengaruh spiritualitas terhadap kinerja, sebagaimana kerangka penelitian di atas maka ada variabel yang dijadikan sebagai variabel intervening. Teknik pengambilan sampel pada penelitain ini dengan menggunakan Probability Sampling yang berupa Simple Random Sampling, yaitu teknik pengambilan sampel secara acak tanpa memperhatikan strata yang ada dalam populasi tersebut (Arikunto, 2006). Populasi penelitian ini adalah seluruh guru SMP Muhammadiyah di Kabupaten Magelang yang berjumlah 370 guru. Adapun sampel yang digunakan adalah sebanyak 185 guru. Penelitian ini dilakukan pada Bulan Februari-Maret 2019. Teknik pengambilan data menggunakan angket. Untuk melakukan analisis data pada penelitian ini, maka digunakan (1) teknik analisis dengan statistik diskriptif; (2) teknis analisis regresi ganda; dan (3) teknik analisis jalur (path analysis).

\section{HASIL DAN PEMBAHASAN}

\section{Spiritualitas Guru SMP Muhammadiyah di Kabupaten Magelang}

Variabel spiritualitas dalam penelitian ini diperoleh dengan menjumlahkan total skor spiritualitas dan selanjutnya dikategorikan menjadi 5 kategori, yaitu sangat baik, baik, cukup, kurang dan sangat kurang. Hasil analisis statistik deskriptif tentang spiritualitas guru SMP Muhammadiyah di Kabupaten Magelang dapat dilihat pada Tabel 1.

Tabel 1. Distribusi frekuensi spiritualitas guru SMP Muhammadiyah di Kabupaten Magelang

\begin{tabular}{ccccc}
\hline No. & Interval & $\begin{array}{c}\text { Frekuensi/ } \\
\text { Jumlah }\end{array}$ & Prosentase $(\%)$ & Predikat \\
\hline 1 & $\mathrm{X}>134,47$ & 12 & 7,0 & Sangat Baik \\
\hline 2 & $124,16-134,47$ & 43 & 25,1 & Baik \\
\hline 3 & $113,85-124,16$ & 56 & 32,7 & Cukup \\
\hline 4 & $103,53-113,85$ & 55 & 32,2 & Kurang \\
\hline 5 & $\mathrm{X}<103,535$ & 5 & 2,9 & Sangat Kurang \\
\hline
\end{tabular}

Hasil analsisis deskriptif menunjukkan bahwa 12 responden $(7,0 \%)$ memiliki spritualitas sangat baik, 43 responden $(25,1 \%)$ memiliki spiritualitas baik, 56 responden $(32,7 \%)$ memiliki spiritualitas cukup, 55 responden $(32,2 \%)$ memiliki spiritualitas kurang, serta 5 responden $(2,9 \%)$ memiliki spiritualitas sangat kurang. Skor terendah 94, skor tertinggi 151, serta skor rata-rata 119,17.

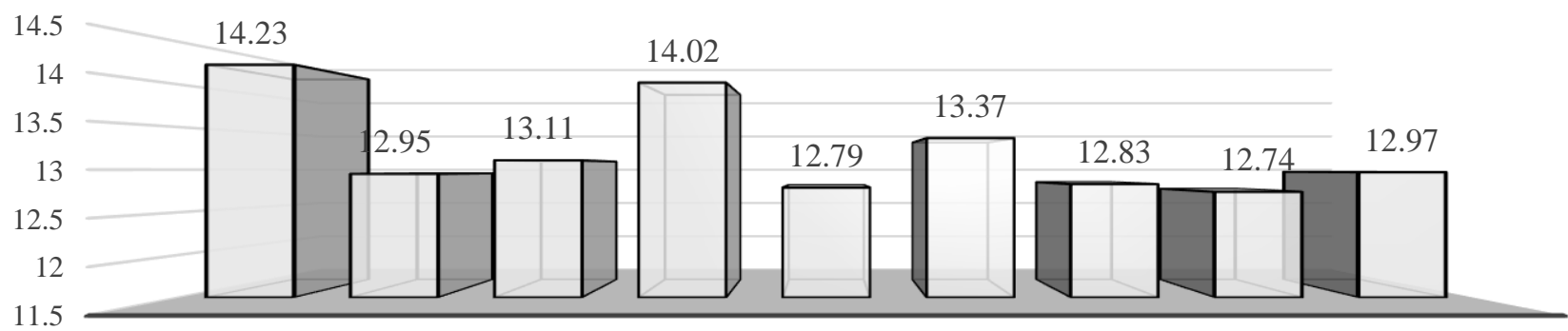

Dimensi 1 Dimensi 2 Dimensi 3 Dimensi 4 Dimensi 5 Dimensi 6 Dimensi 7 Dimensi 8 Dimensi 9

Gambar 2. Dimensi spiritualitas guru SMP Muhammadiyah di Kabupaten Magelang. Keterangan: Dimensi $1=a$ transcendent dimension; Dimensi $2=$ meaning and purpose in life; Dimensi 3= mission in life; Dimensi $4=$ sacredness of life; Dimensi $5=$ material values; Dimensi $6=$ altruism; Dimensi $7=$ idealism; Dimensi $8=$ awareness of the tragic; Dimensi $9=$ fruits of spirituality

Berdasarkan Gambar 2, jika dilihat dari sisi setiap dimensinya, dimensi spiritualitas yang paling tinggi nilainya adalah dimensi transenden. Hal ini menunjukkan bahwa guru memiliki sikap hidup bahwa ibadah merupakan tujuan dari pekerjaan yang dilakukan dan bukan 
mencari materi belaka. Dimensi transenden memberikan gambaran bahwa keimanan merupakan dasar dalam pengembangan perilaku dan berperan memberikan makna yang mengarahkan tujuan hidup manusia hanya kepada Allah SWT. Nilai-nilai transendental inilah yang akan membimbing manusia menuju nilai-nilai luhur kemanusiaan universal.

Berdasarkan wawancara dengan Kepala Sekolah (Wawancara, 15 September 2015), didapatkan hasil bahwa spiritualitas guru ratarata baik, meskipun belum merata. Hal ini dapat dilihat dari bagaimana para guru mengekspresikan keinginan diri untuk mencari makna dan tujuan dalam hidup yang terlihat dari bagaimana mereka memaknai pekerjaan, yang didasarkan pada serangkaian nilai-nilai pribadi yang sangat dipegang oleh seorang guru. Misalnya, etos ibadah menjadi dasar dan pijakan dalam perilaku mereka ketika bekerja. Hal ini dapat dirasakan dari kata-kata dan semangat mereka pada saat bekerja, yang ditunjukkan dengan kata kata positif dalam menyikapi pekerjaan.

Akibat dari hal di atas, menurut Kepala Sekolah, guru yang memiliki spiritualitas yang baik berdampak pada bagaimana dia menghadapi pekerjaan, yaitu mengedepankan dalam melaksanakan tugas secara profesional dan ikhlas karena Allah SWT tanpa motivasi lain. Dia memandang bahwa tugas sebagai amanah yang harus ditunaikan sebaik-baiknya karena memang begitu seharusnya (tanpa pamrih). Adapun imbalan yang diberikan merupakan akibat sampingan) dari pengabdian dirinya yang murni tersebut.

Akibat dari hal di atas maka guru dalam bekerja akan memiliki semangat pantang menyerah. Karena dari pekerjaan, mereka akan mendapatkan manfaat dalam dirinya. Dia akan mampu mempertahankan prinsip yang dia pegang, dan tidak mudah berbelok arah, meskipun ada godaan di dalamnya.

\section{Modal Psikologis Guru SMP Muhammadiyah di Kabupaten Magelang}

Variabel Modal Psikologis diperoleh dengan menjumlahkan total skor modal psikologis dan selanjutnya dikategorikan menjadi lima kategori, yaitu Sangat Baik, Baik, Cukup, Kurang, dan Sangat Kurang. Adapun kategori tersebut dibuat dengan ketentuan sebagaimana Tabel 1. Hasil analisis statistik deskriptif tentang modal psikologis guru SMP Muhammadiyah di Kabupaten Magelang dapat dilihat pada Tabel 2 .

Tabel 2. Distribusi frekuensi modal psikologis guru SMP Muhammadiyah di Kabupaten Magelang

\begin{tabular}{ccccc}
\hline No. & Interval & Frekuensi & Prosentase $(\%)$ & Predikat \\
\hline 1 & $\mathrm{X}>79,80$ & 12 & 7,0 & Sangat Baik \\
\hline 2 & $73,05-79,80$ & 27 & 15,8 & Baik \\
\hline 3 & $66,30-73,05$ & 81 & 47,4 & Cukup \\
\hline 4 & $59,55-66,30$ & 43 & 25,1 & Kurang \\
\hline 5 & $\mathrm{X}<59,55$ & 6 & 3,5 & Sangat Kurang \\
\hline
\end{tabular}

Dari hasil analisis modal psikologis menunjukkan bahwa mayoritas responden $(70,2 \%)$ minimal memiliki modal psikologis tergolong cukup, baik, dan sangat baik. Hal ini berarti guru dalam pribadinya memiliki karakter positif (1) self-efficac (efikasi diri); (2) hope (harapan); (3) optimism (optimisme); dan (4) resiliency (daya lenting). Perbandingan masingmasing dimensi modal psikologis, dapat dilihat pada Gambar 3.

Apabila dilihat lebih lanjut setiap dimensinya, keseluruhan dimensi menunjukkan hasil yang bagus, yaitu menunjukkan modal psikologis terjadi secara menyeluruh pada setiap dimensinya, dan dimensi yang paling tinggi skornya adalah dimensi resiliency (daya lenting). Hal ini berarti guru memiliki kekuatan pantang menyerah dalam mengemban tanggung jawab pekerjaan, dan berani menghadapi tantangan dalam pekerjaan.

Guru yang memiliki resiliency yang tinggi akan mampu mengambil langkahlangkah yang paling tepat untuk mengatasi masalah serta mampu menyesuaikan diri terhadap tuntutan situasi, lingkungan sekitar dan zamannya. Resiliency yang tinggi akan menjadikan guru memiliki kemampuan mengubah tantangan menjadi peluang, serta 
kapasitas untuk merespons secara sehat dan produktif ketika berhadapan dengan permasalahan dan pada akhirnya guru mampu mengelola tekanan hidup sehari-hari.

Guru yang memiliki resiliency memiliki kemampuan untuk kembali dari situasi keterpurukan serta memiliki kesukaan terhadap kegiatan-kegiatan yang positif dan menantang, Di samping itu juga resiliency akan membuat individu mampu dalam mengatasi tantangan hidup serta mempertahankan energi yang baik sehingga dapat melanjutkan hidup secara sehat.

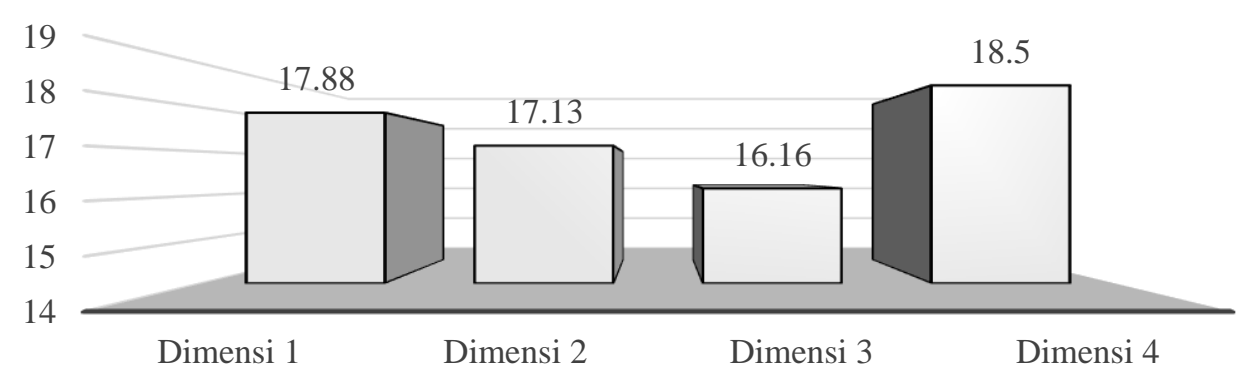

Gambar 3. Dimensi modal psikologis guru SMP Muhammadiyah di Kabupaten Magelang. Keterangan: Dimensi 1= Self-efficacy; Dimensi 2= Hope; Dimensi 3= Optimism; Dimensi $4=$ Resiliency

Berdasarkan wawancara dengan Kepala Sekolah, didapatkan gambaran tentang modal psikologis guru cukup baik, meskipun belum merata (Wawancara Maret 2019). Guru memiliki kepercayaan diri yang baik. Hal ini terlihat pada saat ada tantangan dalam pekerjaan yang menuntut untuk segera diselesaikan, guru selalu berupaya keras untuk mengatasi tantangan-tantangan pada tugasnya. Di samping itu juga guru terlihat selalu berupaya menyelesaikan dengan baik dan berusaha meraih keberhasilan dalam menyelesaikan tugas-tugasnya.

Berkenaan dengan sikap optimis, guru memiliki sikap optimistis yang cukup bagus terhadap keberhasilan masa sekarang atau masa yang akan datang dalam pekerjaan di sekolah. Sikap optimistis ini, menurut Kepala Sekolah akan berpengaruh terhadap upaya kerja keras dalam rangka mencapai keberhasilan.

Guru juga memiliki daya tahan (resilience) cukup baik, meskipun ini belum merata. Kemampuan untuk bertahan dalam menghadapi kesulitan dan tantangan demi mencapai tujuan dapat dirasakan dalam suasana kerja keseharian di sekolah, terutama pada saat dihadapkan pada masalah dan kesulitan, guru mampu mempertahankan, tabah, dan bahkan mampu melampaui masalah tersebut untuk mencapai keberhasilan. Namun demikian, sekali lagi fakta menunjukkan tidak semua guru memiliki daya tahan yang tinggi dalam menghadapi tantangan. Gambaran ini menjadi sangat terasa pada saat sekolah mempunyai pekerjaan yang banyak. Misalnya pada saat Akreditasi, persiapan ujian, serta persiapan lomba, serta acara lain yang membutuhkan energi banyak.

\section{Kinerja Guru SMP Muhammadiyah di Kabupaten Magelang}

Variabel kinerja diperoleh dengan menjumlahkan total skor kinerja guru dan selanjutnya dikategorikan menjadi 5 kategori yaitu sangat baik, baik, cukup, kurang dan sangat kurang. Adapun kategori tersebut dibuat dengan ketentuan sebagaimana Tabel 2. Hasil analisis statistik deskriptif tentang kinerja guru SMP Muhammadiyah di Kabupaten Magelang dapat dilihat pada Tabel 3.

Tabel 3. Tabel distribusi frekuensi kinerja guru SMP Muhammadiyah di Kabupaten Magelang

\begin{tabular}{ccccc}
\hline No. & Interval & Frekuensi & Prosentase $(\%)$ & Predikat \\
\hline 1 & $X>138,41$ & 16 & 9,4 & Sangat baik \\
\hline 2 & $132,5-138,41$ & 29 & 17,0 & Baik \\
\hline 3 & $114,77-126,59$ & 82 & 48,0 & Cukup \\
\hline 4 & $102,95-114,77$ & 40 & 23,4 & Kurang \\
\hline 5 & $X<102,95$ & 4 & 2,3 & Sangat kurang \\
\hline
\end{tabular}


Hasil analisis deskriptif menggambarkan bahwa 16 responden $(9,4 \%)$ memiliki kinerja sangat baik, 29 responden $(17,0 \%)$ memiliki kinerja baik, 82 responden $(48 \%)$ memiliki kinerja cukup, 40 responden $(23,4 \%)$ memiliki kinerja kurang, serta 4 responden $(2,3 \%)$ memiliki kinerja sangat kurang. Hal ini berarti bahwa $74,4 \%$ guru memiliki kinerja cukup, baik, dan sangat baik. Perbandingan masing-masing dimensi kinerja guru, dapat dilihat pada Gambar 4.

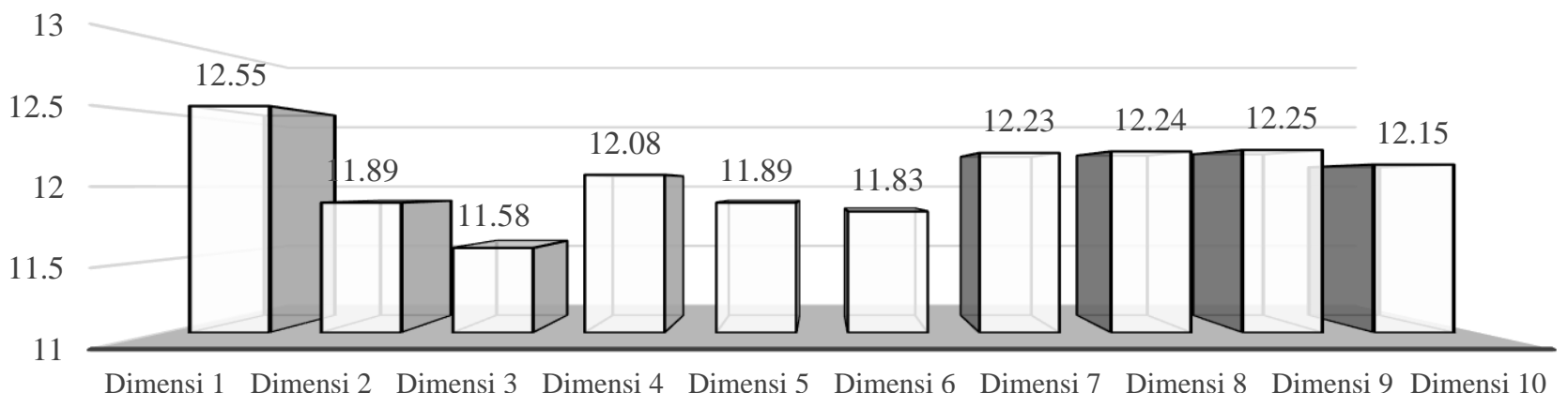

Gambar 4. Grafik dimensi kinerja guru SMP Muhammadiyah di Kabupaten Magelang Keterangan

Dimensi 1 Professional knowledge

Dimensi 2 Instructional planning

Dimensi 3 Instructional strategies

Dimensi 4 Differentiated instruction

Dimensi 5 Assessment itrategies
Dimensi 6

Dimensi 7

Dimensi 8

Dimensi 9

Dimensi 10
Assessment uses

Positive learning environment

Academically challenging environment

Professionalism

Communication
Berdasarkan Gambar 4, keseluruhan dimensi menunjukkan hasil yang bagus, hal ini menunjukkan bahwa kinerja terjadi secara menyeluruh pada setiap dimensinya, dan dimensi yang paling tinggi skornya adalah dimensi profesional knowledge. Guru yang memiliki profesional knowledge yang baik yaitu guru memiliki pemahaman tentang kurikulum, isi pelajaran, pengetahuan pedagogis, beberapa bidang ilmu yang secara sengaja dan kemudian diaplikasikan dalam pembelajaran dalam rangka memberikan pengalaman belajar yang relevan. Selanjutnya, hasil wawancara dengan Kepala Sekolah berkenaan kinerja guru diketahui bahwa sebagian besar kepala sekolah menilai kinerja guru sudah mendekati standar kinerja yang berlaku.

Pada aspek perencanaan, guru mampu menyusun program tahunan, program semester, silabus, dan RPP, serta hasilnya sudah cukup lebih baik serta telah disusun lebih awal dari sebelumnya (Wawancara Maret 2019). Selain itu, RPP juga telah disusun untuk setiap mata pelajaran. Sebagian guru membuat satu semester sekaligus, sedangkan sebagian guru telah membuat RPP pada setiap tatap muka (disesuaikan dengan kebutuhan). Pada aspek pelaksanaan pembelajaran, guru sudah menggunakan berbagai media/alat peraga. Namun pada tataran metode pembelajaran, belum semua guru menggunakan model-model pembelajaran aktif (Wawancara, Maret 2019).

Meski demikian, tidak satupun dari responden kepala sekolah yang menyatakan kinerja guru sudah mencapai kinerja yang optimal atau mencapai standar kinerja yang berlaku, bahkan ada yang menilainya hanya mendekati standar kinerja. Pada aspek penilaian, guru sudah bagus dalam mempersiapkan instrumen penilaian. Hal ini dapat dilihat dari bagaimana guru-guru selalu menggunakan pedoman dalam membuat alat evaluasi. Misalnya penyusunan instrumen penilaian mesti didahului dengan pembuatan kisi-kisi, dan bahkan sebagian guru juga melakukan analisis butir soal.

Dalam konteks menciptakan pembelajaran yang bermutu, guru menunjukkan komitmen etika profesi dan komitmen terhadap visi dan misi sekolah, serta berpartisipasi dalam pengembangan profesionalisme untuk mendukung keberhasilan pembelajaran siswa. Di samping itu juga guru sangat memperhatikan berkomunikasi secara efektif dengan siswa, orang tua atau wali, guru dalam rangka meningkatkan keberhasilan belajar siswa. 
Selanjutnya wawancara tambahan yang dilakukan dengan kepala sekolah (Maret 2019) didapatkan keterangan tambahan berkenaan dengan faktor penghambat dan pendukung kinerja guru.

\section{Pengaruh Spiritualitas terhadap Kinerja Melalui Modal Psikologis Guru SMP Muhammadiyah di Kabupaten Magelang}

Hasil analisis data jalur pengaruh spiritualitas terhadap kinerja melalui modal psikologis guru SMP Muhammadiyah di
Kabupaten Magelang dapat dilihat pada Tabel 4.

Nilai koefisien jalur pengaruh spiritualitas terhadap modal psikologis $\left(\mathrm{X}-\mathrm{Z}_{2}\right)$ menunjukkan angka sebesar 0,556 dan nilai koefisien jalur modal psikologis terhadap kinerja $\left(\mathrm{Z}_{2}-\mathrm{Y}\right)$ sebesar 0,216, sehingga pengaruh tidak langsung spiritualitas terhadap kinerja melalui modal psikologis sebagai variabel intervening $\left(\mathrm{X}-\mathrm{Z}_{2}-\mathrm{Y}\right)$ sebesar $12,0 \%$ $(0,556$ X $0,216=0,120)$. Koefisien pengaruh langsung spiritualitas terhadap kinerja (X-Y) sebesar 0,045 , sehingga $0,120>0,045$

Tabel 4. Hasil analisis jalur pengaruh spiritualitas terhadap kinerja melalui modal psikologis guru SMP Muhammadiyah di Kabupaten Magelang

\begin{tabular}{ccccccc}
\hline \multicolumn{7}{c}{ Pengaruh langsung } \\
\hline No. & Koefisien jalur & Beta & Uji t $p$ value & Koefisien & Ket. & Proporsi pengaruh \\
\hline 1 & $\mathrm{X}-\mathrm{Z}_{2}$ & 0,556 & 0,000 & 0,309 & Sign. & $30,9 \%$ \\
\hline 2 & $\mathrm{X}-\mathrm{Y}$ & 0,211 & 0,000 & 0,045 & Sign. & $4,5 \%$ \\
\hline 3 & $\mathrm{Z}_{2}-\mathrm{Y}$ & 0,216 & 0.001 & 0,047 & Sign. & $4,7 \%$ \\
\hline \multicolumn{7}{c}{ Pengaruh Tidak Langsung } \\
\hline 4 & $\mathrm{X}-\mathrm{Z}_{2}-\mathrm{Y}$ & $0,556 \mathrm{X} 0,216=0,120$ & $12,0 \%$
\end{tabular}

Keterangan: $\mathrm{X}=$ Spiritualitas; $\mathrm{Y}=$ Kinerja guru; $\mathrm{Z}_{2}=$ Modal psikologis

Pengaruh tidak langsung spiritualitas terhadap kinerja organisasi melalui modal psikologis, juga lebih besar bila dibandingkan dengan pengaruh langsung spiritualitas terhadap kinerja. Hal ini mengindikasikan bahwa keberadaan modal psikologis dapat memperkuat pengaruh spiritualitas terhadap kinerja guru.

Nilai koefisien variabel spiritualitas, modal psikologis, dan kinerja guru menunjukkan arah positif. Hal ini dapat diartikan bahwa semakin tinggi spiritualitas maka akan meningkatkan komitmen organisasi yang pada akhirnya akan meningkatkan perilaku kewargaorganisasian guru. Dengan kata lain hasil penelitian ini menunjukkan bahwa spiritualitas berpengaruh positif dan signifikan terhadap perilaku kewargaorganisasian melalaui komitmen organisasi.

Hasil penelitiaan ini tidak jauh berbeda dengan penelitian-penelitian sebelumnya. Berdasarkan penelitian Liwarto dan Kurniawan (2015) disimpulkan bahwa variabel psychological capital memiliki hubungan yang signifikan dengan kinerja karyawan. Pada korelasi antara psychological capital dengan kinerja karyawan menunjukkan hubungan yang positif, searah, dan kuat, signifikan. Artinya bahwa kinerja karyawan berhubungan kuat dengan variabel psychological capital. Karyawan yang memiliki rasa percaya diri, harapan, optimisme, rasa pantang menyerah yang tinggi, ia juga akan memberikan hasil kinerja yang baik dan positif, atau juga dapat berlaku sebaliknya.

Hal ini sejalan dengan penelitian Luthans (liwarto dkk, 2015) yang menyimpulkan bahwa modal psikologi keseluruhan para karyawan di China memiliki hubungan positif dengan kinerja yang dinilai oleh para supervisornya. Hal serupa juga terjadi pada penelitian Luthans, Avolio. Spiritualitas juga diasumsikan memiliki pengaruh terhadap kinerja melalui modal psikologis. Penelitian Samiyanto (Ancok, 2011) menunjukkan bahwa ada hubungan yang menarik antara spiritualitas dengan psichological capital. Semakin tinggi tingkat spiritualitas maka semakin tinggi psychological capital manajer dan perilaku kepemimpinannya. Hasil lain dari penelitian ini bahwa spiritualitas tidak berpengaruh langsung 
terhadap kinerja manajer, tetapi melalui variabel mediasi servant leadership

Dengan demikian dapat disimpulkan bahwa spiritualitas memiliki efek terhadap kinerja individu dalam organisasi baik secara langsung maupun melalui modal psikologis. Artinya spiritualitas yang baik seorang guru akan menjadikan modal psikologis guru baik, yang pada akhirnya akan berdampak pada peningkatan kinerja guru..

\section{PENUTUP}

Spiritualitas mengajarkan orang untuk mengekspresikan dan memberi makna pada setiap tindakannya, sehingga bila ingin menampilkan kinerja yang baik maka dibutuhkan kecerdasan spiritual. Spiritualitas memiliki pengaruh terhadap modal psikologis. Selanjutnya, modal psikologis memiliki pengaruh terhadap kinerja individu dalam organisasi.

Hasil penelitian menunjukkan bahwa nilai koefisien jalur pengaruh spiritualitas terhadap modal psikologis menunjukkan angka sebesar 0,556 dan nilai koefisien jalur modal psikologis terhadap kinerja sebesar 0,216, sehingga pengaruh tidak langsung spiritualitas terhadap kinerja melalui modal psikologis sebagai variabel intervening sebesar $12,0 \%$ $(0,556 \times 0,216=0,120)$. Koefisien pengaruh langsung spiritualitas terhadap kinerja $(\mathrm{X}-\mathrm{Y})$ sebesar 0,045 , sehingga $0.120>0,045$

Pengaruh tidak langsung terhadap kinerja organisasi melalui modal psikologis, juga lebih besar bila dibandingkan dengan pengaruh langsung spiritualitas terhadap kinerja. Hal ini mengindikasikan bahwa keberadaan modal psikologis dapat memperkuat pengaruh spiritualitas terhadap kinerja guru.

Nilai koefisien variabel spiritualitas, modal psikologis, dan kinerja guru menunjukkan arah positif. Hal ini dapat diartikan bahwa semakin tinggi spiritualitas maka akan meningkatkan komitmen organisasi yang pada akhirnya akan meningkatkan perilaku kewargaorganisasian guru. Dengan kata lain hasil penelitian ini menunjukkan bahwa spiritualitas berpengaruh positif dan signifikan terhadap perilaku kewarga- organisasian melalaui komitmen organisasi Spiritualitas memiliki efek terhadap kinerja individu dalam organisasi baik secara langsung maupun melalui modal psikologis. Artinya spiritualitas yang baik seorang guru akan menjadikan modal psikologis guru baik, yang pada akhirnya akan berdampak pada peningkatan kinerja guru.

\section{UCAPAN TERIMA KASIH}

Penulis mengucapkan banyak terima kasih kepada semua pihak yang telah memberikan kontribusi pada penelitian ini. Pertama kepada Kepala Puslitbang Pendidikan Agama dan Keagamaan, Badan Litbang dan Diklat, Kementerian Agama RI. Kedua kepada pimpinan lembaga penelitian UM Magelang dan IAIN Curup, Bengkulu yang telah memberikan kesempatan untuk melakukan penelitian kolaborasi tahun 2018. Ketiga, kepada Kepala Sekolah SMP Muhammadiyah se-Kabupaten Magelang yang telah memberikan ijin kepada penulis untuk melakukan penelitian di sekolah tersebut, semua guru pendidikan agama Islam, tenaga kependidikan, serta segenap siswa yang telah memberikan data dan informasi kepada penulis. Semoga penelitian ini dapat memberikan manfaat bagi semua pihak dalam rangka peningkatan kinerja guru di lingkungan SMP Muhammadiyah Magelang.

\section{DAFTAR PUSTAKA}

Adestyani, Francisca Aully, and Harlina Nurtjahjanti. (2013) Hubungan antara psychological capital dengan organizational citizenship behavior pada karyawan PT. PLN (persero) distribusi Jawa Tengah dan Daerah Istimewa Yogyakarta. Empati 2. no. 3 32-41.

Ancok, Djamaludin. (2011) Konstrak Spiritualitas Dan Pengaruhnya Terhadap Psychological Capital, Servant Leadership, dan Kinerja Manajer. Diss. [Yogyakarta]: Universitas Gadjah Mada,

Arikunto, Suharsimi. (2006). Prosedur Penelitian Suatu Pendekatan Praktik. Jakarta: Rineka Cipta. 
Depdiknas. (2005). Undang-undang Guru dan Dosen. Jakarta: Puskur Balitbang Departemen Pendidikan Nasional.

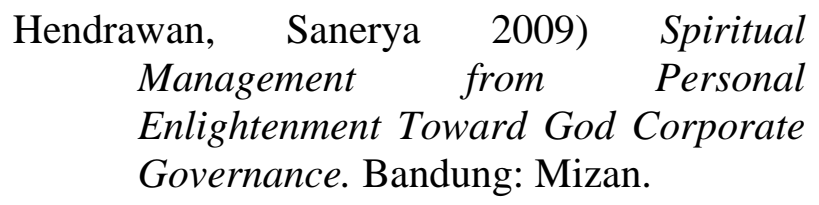

Hendrawan, Sanerya. (2009) Spiritual Management from Personal Enlightenment toward God Corporate Governance. Bandung: Mizan.

Hossein Khanifar Organizational dkk,.(2010). Consideration between Spirituality and Professional Commitment, of Management Faculty European Journal of Social Sciences. 12. no. 4:558.

Javanmard, Habibollah.(2012) The impact of spirituality on work performance. Indian Journal of Science and Technology 5. no. 1:1961-1966

Jena, Lalatendu Kesari, and Rabindra Kumar Pradhan. (2015)Psychological capital and workplace spirituality: Role of emotional intelligence. International Journal of Work Organisation and Emotion7. no. 1: 1-15.

Liwarto, Iwan Hanafi, and Albert Kurniawan. (2015).Hubungan psycap dengan kinerja karyawan PT. X Bandung. Jurnal Manajemen Maranatha 14.2

Malik, Muhammad Ehsan, Basharat Naeem, and Basit Bin Ali. (2011) How do workplace spirituality and organizational citizenship behaviour influence sales performance of FMCG sales force. Interdisciplinary Journal of Contemporary Research in Business 3. no. 8: 610-620.
Mohamed Mousa and Ruth Alas, (2016).Workplace spirituality and organizational commitment : A study on the public schools teachers in Menoufia (Egypt). African Journal of Business Management, 10.no. 10:247-255, DOI: 10.5897/AJBM2016.8031

Pandey, Ashish, Rajen K. Gupta, and A. P. Arora. (2009)"Spiritual climate of business organizations and its impact on customers' experience." Journal of business ethics 88.2: 313-332.

Rahman, Arrafiqur. (2015)Perilaku Spiritual Dan Kepuasan Kerja Karyawan Perusahaan Pabrik Kelapa Sawit. Jurnal Cano Ekonomos4. no. 1: 19-30.

Sulastri, Sulastri, Leonardo Budi Hasiholan, and Moh Mukeri Warso.(2016). Effect of Intellectual Intelligence, Intelligence Emotional and Spiritual Intelligence on The Performance of Employees PT. Tresnamuda Sejati Semarang. Journal of Management2. no. 2

Tart, Charles. (1975) Introduction: Transpersonal Psychologies. New York: Harper \& Row.

Zehra, Shahin, and Akbar Husain. (2015) Relationship between spiritual values and psychological capital among university employees." The New Educational Review 39. no. 1: 253-263.

Zohar, Danah \& Ian Marshall (2002) SQ: Memanfaatkan Kecerdasan Spiritual dalam Berpikir Integralistik dan Holistik untuk Memaknai Kehidupan. Bandung: Mizan. 